\title{
THE FIRST RECORD OF AMETROPUS FRAGILIS ALBARDA, 1878 (INSECTA: EPHEMEROPTERA) FROM CROATIA
}

\author{
Renata ĆuK ${ }^{1}$, Kristina Čmrlec ${ }^{2}$ \& Carlo Belfiore $^{3}$ \\ ${ }^{1}$ Hrvatske vode, Central Water Management Laboratory, Ulica grada Vukovara 220, \\ 10000 Zagreb, Croatia \\ ${ }^{2}$ Lavoslava Ružičke 19, 43500 Daruvar, Croatia \\ ${ }^{3}$ Università di Napoli „,Federico II“ Dipartimento di Zoologia, via Mezzocannone 8, \\ 1-80134 Napoli, Italy
}

Ćuk, R., Čmrlec, K. \& Belfiore, C.: The first record of Ametropus fragilis Albarda, 1878 (Insecta: Ephemeroptera) from Croatia. Nat. Croat., Vol. 24, No. 1, 151-157, 2015, Zagreb.

In the Drava River near Donji Miholjac in January 2014 the species Ametropus fragilis Albarda, 1878 was recorded for the first time in Croatia.

Key words: Ephemeroptera, Ametropus fragilis, The Drava River, Croatia

Ćuk, R., Čmrlec, K. \& Belfiore, C.: Prvi nalaz vodencvijeta Ametropus fragilis Albarda, 1878 (Insecta: Ephemeroptera) u Hrvatskoj. Nat. Croat., Vol. 24, No. 1, 151-157, 2015, Zagreb.

U rijeci Dravi kod Donjeg Miholjca u siječnju 2014. godine po prvi puta je na području Republike Hrvatske utvrđena vrsta Ametropus fragilis Albarda, 1878.

Key words: Ephemeroptera, Ametropus fragilis, rijeka Drava, Hrvatska

\section{INTRODUCTION}

Mayflies (Ephemeroptera) are a very old order of insects, dating from the Carboniferous (Fenton \& Fenton, 1989). Many mayfly species are sensitive to environmental perturbations and pollution so they are recognized as good bioindicators of water quality (SLÁdeČEK, 1973; SowA, 1980; RosEnberg \& ReSH, 1993). They are a critical component in freshwater ecosystems due to their diversity, abundance and their role in nutrient cycles (Moog, 2002). They are cosmopolites and in lotic environments contribute up to $25 \%$ of the total production of zoobenthos in temperate Europe (ElLiot et al., 1988). Their life cycle includes a number of moults (instars) before they emerge as adults. Mayflies are unique among insects because their winged subadult (subimago) goes through an additional moult before it becomes an imago (BRITTAIN \& SARTORI, 2003). Their body shape varies according to habitat.

Taxonomic knowledge of Ephemeroptera of the world has grown very much during the last decades, especially if we consider that the first comprehensive monograph was published more than 120 years ago by EATON (1883-1888). Currently more than 3,045 species (405 genera and 42 families) of extant mayflies are recognized (BRITTAIN \& SARTORI, 2003; BARBER-JAMEs et al., 2008). There are, however, still considerable gaps in our knowledge about the taxonomy, distribution and ecology of European mayfly taxa. More than 342 nominal species (approximately 18 families and 50 genera, depending on taxo- 
nomic view) are recorded throughout Europe (BUFFAGNi et al., 2007; BAUERNFEIND \& SOLDÁN, 2012). New species are still found in Europe (especially in the Mediterranean and the Balkans).

Unfortunately, the Croatian mayfly fauna is poorly investigated and no check-list exists, every new record therefore representing an interesting contribution. Thirty-five species have been cited for Croatia (Buffagni et al., 2007), although Vilenica et al. (2014) announced 62 species.

This paper presents the first finding of the mayfly Ametropus fragilis Albarda, 1878 in Croatia.

\section{MATERIAL AND METHODS}

\section{Research area}

The total length of the Drava River is $749 \mathrm{~km}$ with an associated watershed area of $41,238 \mathrm{~km}^{2}$ (NARODNE NOvINE, 91/08). The river is situated in two ecoregions: the Alps (ER 4) and the Pannonian ecoregion (ER 11) (ILLIES, 1978). The spring is in South Tyrol in Italy (near Lake Dobbiaco), the river continuing through Austria and Slovenia where its upper reaches are used for electricity production. Further downstream it forms most of the border between Croatia and Hungary, then heading back into Croatia again it meets the Danube near the Croatian-Serbian border (near the city of Aljmaš) (Fig. 1).

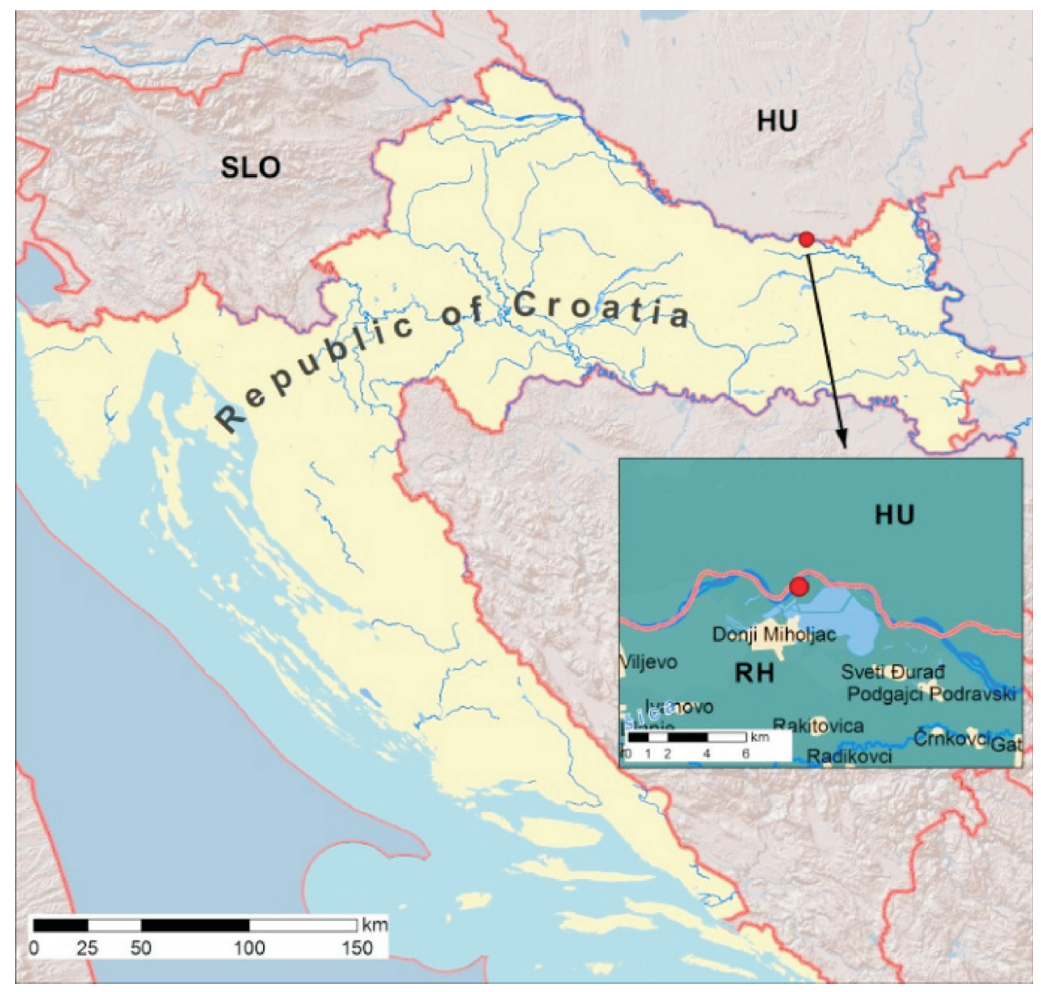

Fig. 1. A map of Croatia with a detail of the studied area 


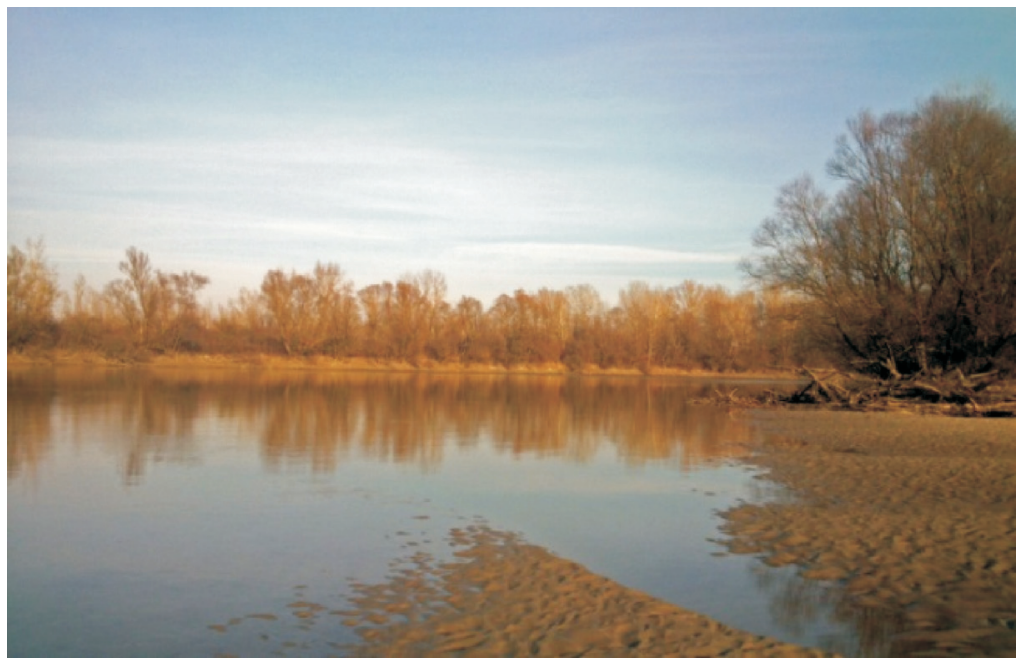

Fig. 2. The Drava River near Donji Miholjac

The length of the Drava River in Croatia is $323 \mathrm{~km}$, a stretch of $136 \mathrm{~km}$ forming the Croatian-Hungarian border) (Narodne Novine, 91/08). In the middle reach, when the river enters Croatia, the Drava River is modified by three large hydropower dams (Varaždin, Čakovec and Dubrava) but parts of the lower reaches are near natural (TomAs et al., 2013).

According to Croatian typology, the Drava River is divided into two types.The middle reach (from Slovenian-Croatian border down to Terezino Polje) is classified among "Very large lowland rivers - lower course of the Mura River and middle course of the Sava and Drava Rivers" while the lower reach belongs among "Very large lowland rivers - lower course of the Sava and Drava Rivers" (including the studied location near Donji Miholjac) (Narodne Novine, 73/13).

The dominant substrates at the studied location were psammal (sand) and argyllal (mud) with fragments of xylal (large logs/dead wood) (HRN EN 16150) (Fig. 2).

\section{Sampling and laboratory methods}

A sample of macrozoobenthos was collected by using a hand net with a mesh size of $500 \mu \mathrm{m}$ according to the AQEM sampling method (HerING et al., 2004). All microhabitats represented with a coverage of more than $5 \%$ were sampled. The collected material was preserved with ethanol in the field and finally stored in ethanol (96\%). Determination of benthic macroinvertebrates was conducted in the laboratory with the use of a binocular stereomicroscope (Olympus SZX9). Specimens of all individual taxa were deposited in the collection of mayflies in the Central Water Management Laboratory of Hrvatske vode.

\section{RESULTS AND DISCUSSION}

One specimen of $A$. fragilis in larval stage was found in the Drava River near Donji Miholjac in January 2014. The morphology of the larva is unique and cannot be misin- 
terpreted. Body length is $12 \mathrm{~mm}$. Overall colouration is light brownish, abdomen along the mediolongitudinal line with reddish brown triangular spots (Fig. 3a). Maxillary and labial palps are three-segmented, glossae and paraglossae with long bristles. Forelegs are short with curved claws and characteristic ventral process on coxae (Fig. 3b). The middle and hind legs are long with short tibia and a very long tarsal claw. Seven pairs
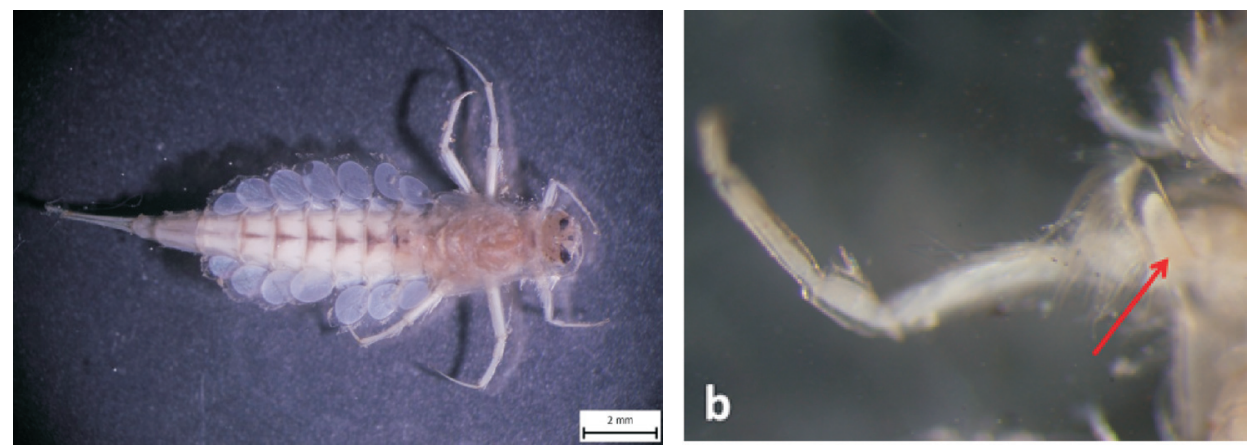

Fig. 3. Ametropus fraglilis Albarda, 1878, larva. a) dorsal view; b) ventral process at the base of fore leg (red arrow)

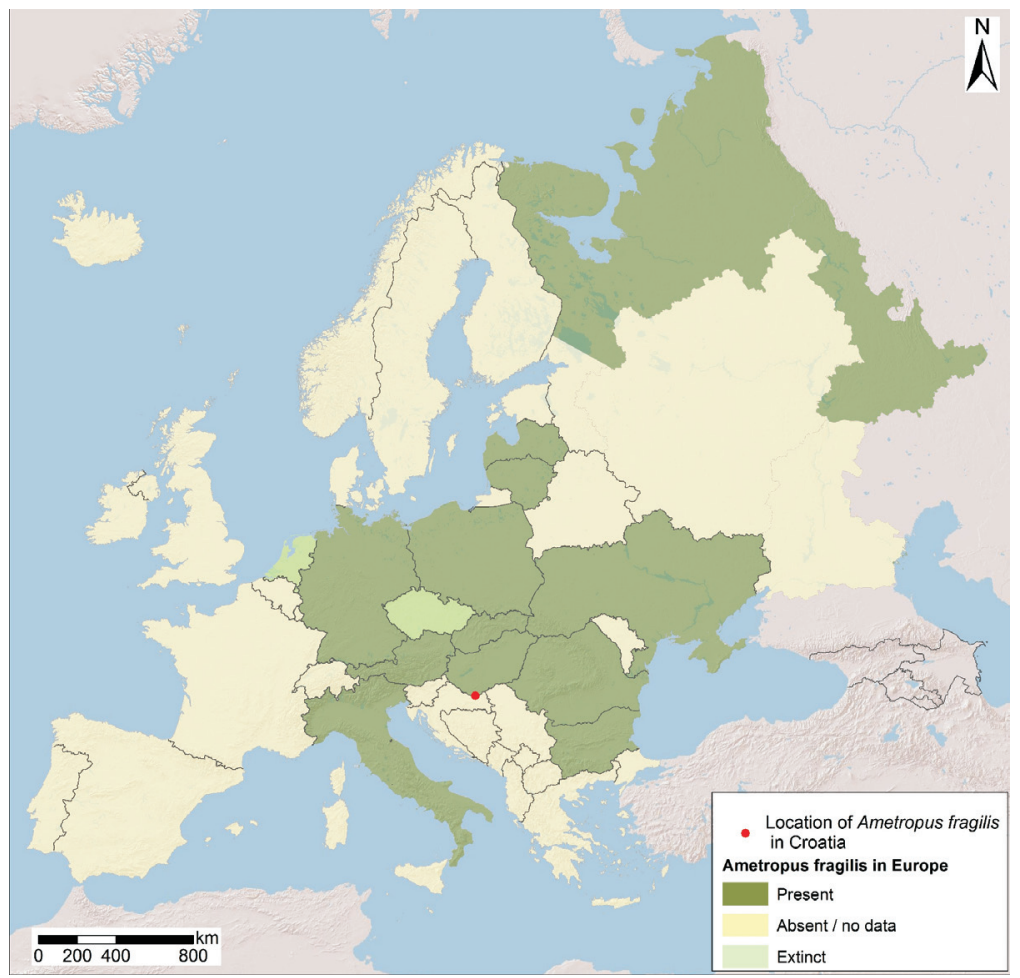

Fig. 4. Distribution of mayfly A. fragilis in Europe (darkgreen) with the location of the first record in Croatia (red spot) 
of single, lateral plate-like gills with a margin that has long setae. Caudal filaments are unicoloured with long dense setae along internal and external margin.

Family Ametropodidae (with $A$. fragilis as the only Palearctic species) belongs to the superfamily Baetoidea. Since Brodskij (1930) described A. eatoni its identity remained doubtful until LANDA (1969) proposed a synonymy between A. fragilis and A. eatoni, tentatively confirmed by Mol (1984) after a study on the lectotype of $A$. fragilis. However, according to KLUGE (2004) the identity of $A$. eatoni is still doubtful.

The distribution of A. fragilis covers Central and Eastern Europe, Siberia (sub. A. eatoni), North-Western Canada and USA. European findings include Germany, Italy, Poland, Austria, Slovakia, Hungary, Bulgaria, Romania, Estonia, Latvia and Lithuania (Thomas \& Belfiore, 2013) (Fig. 4). The species is considered extinct in The Netherlands (Mol, 1985) and the Czech Republic (Soldán \& ZahrádKová, 2000; FARKaČ et al., 2005). First records in Italy (1997) could be a result of human activity, linked to fish restocking in rivers (Turin et al., 1997). According to the available data A. fragilis has not been recorded in Croatia so far (Buffagni et al., 2007; Thomas \& Belfiore, 2013). Although there are findings on the Hungarian side of the Drava River (Horvar et al., 2012), this record on the Croatian side is the first, even if it was expected.

Larvae are psammophilous (sand dwelling) and usually remain hidden in the muddy or sandy substratum (semi-burrowers). Imagines occur in April and May. Preferred microhabitats include submerged logs and accumulations of dead leaves (JAzDzEwsKA, 1973). Loss of habitat and increasing pollution represent a great threat to this species.

Values of the $50 \%$ percentile (the year of 2013) of the most investigated physico-chemical parameters at the investigated location at Donji Miholjac (COD-Mn $=2.8 \mathrm{mgO}_{2} / \mathrm{l}$; $\mathrm{BOD}_{5}=1.8 \mathrm{mgO}_{2} / 1$; amonium $=0.0305 \mathrm{mgN} / \mathrm{l}$; total nitrogen $=1.365 \mathrm{mgN} / \mathrm{l}$; total phosphorous $=0.0595 \mathrm{mgP} / \mathrm{l}$; nitrates $=1.12 \mathrm{mgN} / \mathrm{l})$ indicate good water status while orthophosphates $(0.018 \mathrm{mgP} / \mathrm{l})$ and $\mathrm{pH}(8.1)$ indicate high water status (NARODNE NOVINE, 73/13).

Benthic macroinvertebrate taxa found together with $A$. fragilis at the location investigated were Corophium curvispinum Sars, 1895, Dikerogammarus villosus (Sowinski, 1894) Dikerogammarus sp., Gammarus roeseli Gervais, 1835, Micronecta sp., Simulium sp., Chironomini Gen. sp., Orthocladiinae Gen. sp., Tanypodinae Gen. sp., Oligochaeta Gen. sp., Baetis tracheatus Keffermüller \& Machel, 1967, Siphlonurus sp., Leuctra sp., Viviparus acerosus (Bourguignat, 1862), Stagnicola sp., Corbicula sp. and Hydropsyche sp.

The Saprobic index (PANTLE \& BUCK, 1955) based on benthic macroinvertebrates was calculated according to the saprobic indicator taxa list (Minaljević et al., 2011) and later modified (Mihaljević, personal communication, November 15, 2014). Saprobic index value of 2,12 at the location investigated indicates good water status.

\section{ACKNOWLEDGEMENTS}

We are very grateful to Mladen Plantak, mag.geogr. and dr. sc. Ivan Vučković, dipl. ing.biol. from Elektroprojekt d.o.o., Zagreb, for designing the maps of the research area and distribution. 


\section{REFERENCES:}

Albarda, H., 1878: Description of three new European Ephemeridae. Entomologist's monthly Magazine 15, 128-130.

Barber-James, H. M., Gattolliat, J. L., Sartori M. \& Hubbard, M. D., 2008: Global diversity of Mayflies (Ephemeroptera, Insecta) in freshwater. Hydrobiologia (The Hague) 595, 339-350.

BAuernfeind, E. \& SoldÁn, T., 2012: The Mayflies of Europe (Ephemeroptera). - Apollo Books, Ollerup, Denmark, pp. 781.

Brittain, J. E. \& Sartori, M., 2003: Ephemeroptera (Mayflies). In: Resh, V. H. \& Cardé, R. T. (eds), Encyclopedia of insects. Academic Press, Amsterdam, p. 373-380.

BrodskiJ, K., 1930: K poznaniyu Ephemeroptera Yuzhnoy Sibiri. Entomologicheskoe Obozrenie 24(1-2), 31-40.

Buffagni, A., Armanini, D. G., Cazzola, M., Alba-Tercedor, J., López-Rodríguez, M. J., Murphy, J., SAndin, L. \& Schmidt-Kloiber, A., 2007: Ephemeroptera Indicator Database. Euro-limpacs project, Workpackage 7 - Indicators of ecosystem health. Available from www.freshwaterecology.info (version 5.0 - 02/2007) (accessed on 25.10.2014).

EATon, A. E., 1883-1888: A revisional monograph of Recent Ephemeridae or mayflies. Transactions of the Linnean Society of London, Zoology 3(2), 1-352.

Elliott, J. M., Humpesch, U. H. \& Macan, T.T., 1988: Larvae of the British Ephemeroptera. A key with ecological notes. Freshwater Biological Association Scientific Publication 49, pp. 145.

FARKAČ, J., KRÁL, D. \& ŠKorpíK, M., 2005: Červený seznam ohrožených druhů České republiky. Bezobratlí. List of threatened species in the Czech Republic. Invertebrates. Agentura ochrany prírody a krajiny ČR, Praha, pp. 760 .

Fenton, C. L. \& Fenton, M. A., 1989: The Fossil Book: A record of prehistoric life. Doubleday, New York, pp. 740.

Hering, D., Moog, O., Sandin, L. \& Verdonschot, P. F. M., 2004: Overview and application of the AQEM assessment system. Hydrobiologia (The Hague) 516, 1-20.

Horvai, V., Czirok, A., Lőkkős A., Borza, P., Bódis, E. \& DeÁk C., 2012: Újabb adatok a Magyar-Horvát szakasz ripális régiójának makroszkopikus gerinctelen faunájáról. Acta Biologica Debrecina Oecologia Hungarica 28, 109-120.

HRN EN 16150, 2012: Water quality - Guidance on pro-rata Multi-Habitat sampling of benthic macroinvertebrates from wadeable rivers, pp. 12.

ILlies, J., 1978: Limnofauna Europaea. Gustav Fischer Verlag, Stuttgart, pp. 532.

JAzDzewskA, T., 1973: Notes on the biology and ecology of the mayfly Ametropus eatoni Brodskij (Ephemeroptera). Polskie Pismo entomologiczne 43, 469-477.

Kluge, N. J., 2004: The Phylogenetic System of Ephemeroptera. Kluwer Academic Publishers. Dordrecht. $442 \mathrm{p}$.

LAndA, V., 1969: Jepice - Ephemeroptera. Fauna ČSSR, 18. Československé Academie Věd, Praha, pp. 350.

Mihaljević, Z., Kerovec, M., Mrakovčić, M., Plenković, A., Alegro, A. \& Primc-Habdija, B., 2011: Testiranje bioloških metoda ocjene ekološkog stanja (Okvirna direktiva o vodama, 2000/60/EC) u reprezentativnim slivovima Panonske i Dinaridske ekoregije. PMF, Sveučilište u Zagrebu, Zagreb.

Mol, A. W. M., 1984: Notes on type-specimens of Ephemeroptera (Insecta), described by Herman Albarda, with special reference to Ametropus fragilis Alb. Zoologische Mededelingen Leiden 59 (5), 55-59.

Mol, A. W. M., 1985: Een overzicht van de Nederlandse haften (Ephemeroptera) 2. Overige families. Entomologische Berichten, Amsterdam 45 (9), 128-135.

Moog, O., 2002: Fauna Aquatica Austriaca. Wasserwirtschaftskataster, Bundesministerium für Land- und Forstwirtschaft, Wien.

NARODNE NOvine, 2013: Uredba o standardu kakvoće voda (Regulation on water quality standard). No. 73/13.

Narodne novine, 2008: Strategija upravljanja vodama (Water Management Strategy). No. 91/08.

Pantle, R. \& Buck, H.,1955: Die biologische Überwachung der Gewässer und die Darstellung der Ergebnisse, GWF (Wasser/Abwasser) 96, 604-620.

Rosenberg, D. M. \& Resh, V. H., 1993: Freshwater Biomonitoring and Benthic Macroinvertebrates. Chapman and Hall, New York, pp. 488. 
SLÁDEČEK, V., 1973: System of Water Quality from the Biological point of view. Archiv für HydrobiologieBeiheft Ergebnisse der Limnologie 7, 1-218.

Soldán, T. \& Zahrádková, S., 2000: Ephemeroptera of the Czech Republic: Atlas of distribution. In: HeLEŠic, J. \& ZAhrádKová, S. (eds), Fauna Aquatica Europeae Centralis. Masaryk University Brno, Biodiversity Working Group, pp. 401.

SowA, R., 1980: La zoogeographie, l'ecologie et la protection des Ephéméroptères en Pologne, et leur utilisation en tant qu'indicateurs de la pureté des eaux courantes. In: Flannagan, J. F.\& Marshall, K. E. (eds), Advances in Ephemeroptera Biology. Plenum, New York, p. 141-154.

Thomas, A. \& Belfiore, C., 2013: Fauna Europaea: Ephemeroptera. Fauna Europaea version 2.6.2., http:// faunaeur.org (accessed October 25, 2014).

Tomas, D., Ćuk, R., Senta Marić, A. \& Mijatović, I., 2013: Assessment of the Drava river (Croatia) by Water Quality Index Method. Fresenius Environmental Bulletin 22(3a), 904-913.

Turin, P., Bilò, M.F. \& Belfiore, C., 1997: Primo rinvenimento in Italia di Ametropus fragilis Albarda 1878 (Ephemeropera: Ametropodidae). Lavori della Società Veneziana di Scienze Naturali 22, 7-14.

Vilenica, M., Gattolliat, J.-L., Ivković, M., Kučinić, M., MičEtić Stanković, V., Mihaljević, Z. \& SaRTORI, M., 2014: The mayfly fauna (Insecta, Ephemeroptera) of the Plitvice lakes National park, Croatia. Natura Croatica 23(2), 349-363.

\title{
SAŽETAK
}

\section{Prvi nalaz vodencvijeta Ametropus fragilis Albarda 1878 (Insecta: Ephemeroptera) u Hrvatskoj}

\author{
R. Ćuk, K. Čmrlec \& C. Belfiore
}

Vodencvjetovi (Ephemeroptera) su red kukaca koji se zadržavaju uz vode, dok ličinke žive u vodi. Mnoge su vrste osjetljive na različita zagađenja pa su dobar indikator kakvoće voda. Fauna vodencvjetova u Hrvatskoj je slabo istražena i check-lista još uvijek ne postoji.

U rijeci Dravi kod Donjeg Miholjca u siječnju 2014. godine prvi put je na području Republike Hrvatske zabilježena vrsta Ametropus fragilis Albarda, 1878 iz porodice Ametropodidae. Vrsta je utvrđena na temelju prikupljene ličinke. 